\title{
北洋鮭鱒流刺網の色彩が罹網尾数に及ぼす影響
}

\author{
小池篤 \\ (東京水産大学) \\ Comparative Efficiency of Differently Coloured Gill-Net in \\ the North Sea Salmon Fishing \\ Atushi Kolke
}

\begin{abstract}
Salmon gill-nets intentionally coloured blue-green (mizu-iro), cutch-brown (katti-iro), and gray (usuzumi-iro), respectively, were examined in an actual operation on the fishing ground in the northern waters. Counting the fish coming entangled in each coloured net, it was found that the fish-entangling abilities of these nets arrange in the following order: gray = bluegreen $>$ cutch-brown (Figs. 2 and 3 ; Tables 1 and 2).

Since the present results deal with some different kinds of salmon and trout all together, a further examination will be necessary with each fish species separately, and also with various degrees of lightness in water.
\end{abstract}

\section{8. 調查方法}

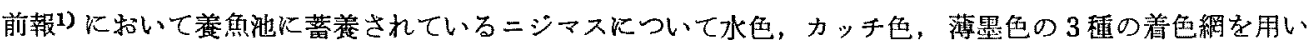
たところカッチ色の着色網の罹網がマッ゙メ及び昼間炕最も不良と考えられたので前記 3 種の着色網の使用 された北太平洋鮭鱒流刺絧について比較检討してみた。

調查仕 1956 年出鮇した大洋漁業株式会社調査船， $\alpha$ 丸（調查期間 5 月 30 日〜 6 月 14 日）及び $\beta$ 丸(調 査期間 6 月 14 日〜 8 月 8 日)によつて行われた。尚両船の操業海面はフリューシャン列島南西側海域であつ て，操業に使用した漁網の色彩は前報》で使用したものと全く同じ水色，カッチ色,薄畦色の 3 種で,着色網 の配置は Fig. 1 の如く $\alpha$ 丸の使用漁具では中央部分はカッチ色 90 反 150 反で (アミラン 210 デニー ル，3/15，4.1 寸目）この網の一端に，薄墨色及びカッチ色（何れもアミラン 210 デニール，4/18, 4.1 寸 目）夫々 10 反宛を連結し，之を 1 単位として交互に薄墨色とカッチ色の着色網 1 戦位〜 2 戦位を連結した

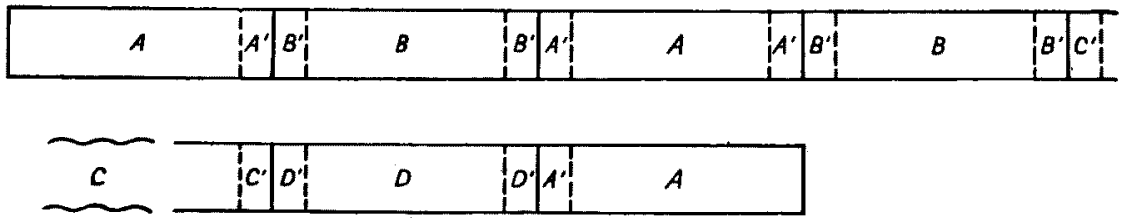

Fig. 1. Construction of the gill nets used in the present research. $A$ section is centre part of cutch-brown net, $A^{\prime}$ and $C^{\prime}$ are edge parts of cutchbrown; $B$ is centre part of blue-green net; $C$ is cutch-brown net for the contrast; $D$ and $D^{\prime}$ gray nets. 
ものを接続し，他端にはカッチ色及び水色を（何れもアミラン 210 デニール，3/15, 4.1 寸目）夫ネ 10 反宛 を連結し，これを 1 弾位として交互にカッチ色と水色の着色網 2 絆位〜 3 単位を連結したるのを接続してあ る。B丸では, 主要部分はカッ千色 75 反〜90反で，(フミラン 210 デニール，4/18, 4.1 寸目）この網の 一端征墨色及びカッ千出（何れるアミラン 210 デニール，4/18，4.1 寸目）夫々 10 反宛を連結し，こ れを 1 単位として交互に薄墨色とカッチ色 5 単位〜14 単位を連結したものを接続してむる。 $\alpha$ 丸の場合は 両側， $\beta$ 丸の場合は片側に接続された 10 反宛を政位として交互に筫つた着色網が連結された部分の網を試 験網と呼び，之等が按続されているカッチ色の刺網の主要部分の網を対照網と呼らこことにする。

このような漁具で操業した結果から船別, 日別に試験網に依る䍜網尾数を各単位每に投緍順に記録し，又

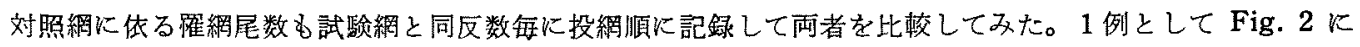
$\alpha$ 丸の 5 月 4 日及び 5 月 18 日の場合を示す。但し試験網は最初 10 反宛を単位として連結したが，漁期の移 行沉つれて破絧その他の事故により次第にその反数が减少し常に一定ではなかつた。従つて日別に各単位の 平均反数を求め，対照絧の単位もこの平均反数を用いた。対照網の各単位当りの䍜網状況が魚群の分布状態 を示するのと考光て，Fig. 2 をるると試駼網の罪網分布と対照網のそれとは異つた状態を示している。a丸

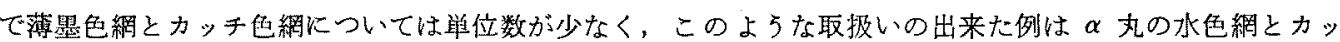
于色網で 9 回中差異のある場合 3 回，及 $\beta$ 丸では 12 回中薄墨色網とカッチ色䋧で 3 回にずぎかかたが，

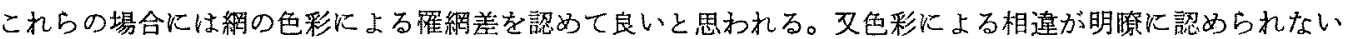
場合は，魚群の罹網する時刻の照度が函めて低かつたために網の色彩による差異が認められなかつたのでは ないかと推定されるが，この点については今後の研菀に待ちたい。鮭鰾刺網の色彩による漁獲の良否を調べ る場合は操業結果の全般に亘つて取投う方が実際的であると思われるので以下に調查結果を述べる。

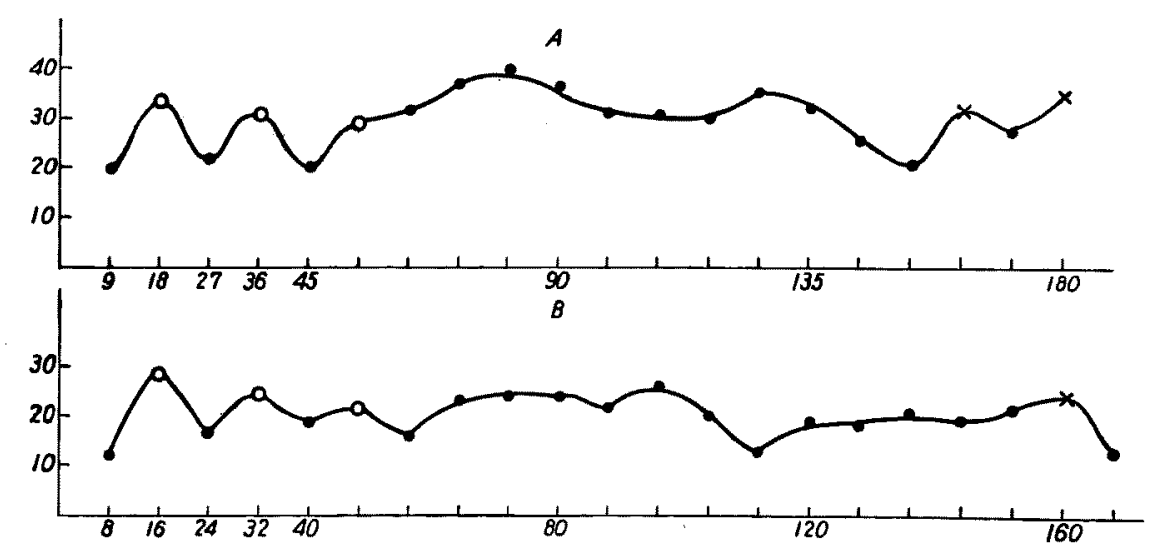

Fig. 2. An example showing the distribution of fish entanglement for the nets differing in colour. $\bigcirc$, blue-green net; $\bullet$, cutch-brown net; $\times$, gray net. $A$, coordinate shows the number of fish entangled in for every 9 tan of net, abscissa left to right the order of operation of gill-net fishing (May 4, $\alpha$ maru). $B$, the same as above, but the number of fish entangled is for every 8 tan of net (May 18, $\alpha$ maru).

\section{\$. 調查結果}

試駼網は夫々の着色網を原則として 10 反を戦位として組合せて用いられているので，夫々の単位内で異 つた着色網が連接する附近では色彩の対比的現象が予想される。そこで夫々の単位内で色彩の哄る網が連接 するる各 1 反すつと，他の部分とに分けて日別の反当り罹網尾数を計算し， $\alpha$ 丸のカッチ色網と水色網の埸合 
を Table 1 K又全ての調查例の平均を Table 2 飞示す。 $\alpha$ 丸の薄堽色網とカッチ色網で操業回数 19 回, 薄壆色網の総投網反数 221 反，㴔獲尼数 890 尾，カッ千色網は 312 反，534 尾。水色網とカッ千色網で操 業回数 11 回, 水色網 247 反, 695 尾, カッ千色網 268 反, 623 屁。 $\beta$ 丸で薄墨色網とカッ千色網で操業 回数 20 回，薄墨色網 967 反，2,010 尾，カッチ色網 930 反，1,545 尾であつた。Table 2 上り色彩によ る対比的な現象も多少含まれる場合も予想されるが，1単位中汇含まれる端の網は中央の網に比べその反数 が少ないので各色彩別比端の部分と中央の部分を加光て日別の色彩別反当り籊網尾数を求め, 日別, 船別,

Table 1. An example list showing the number of fish actually entangled in the differently coloured nets, the effect of colour contrast being taken in account.

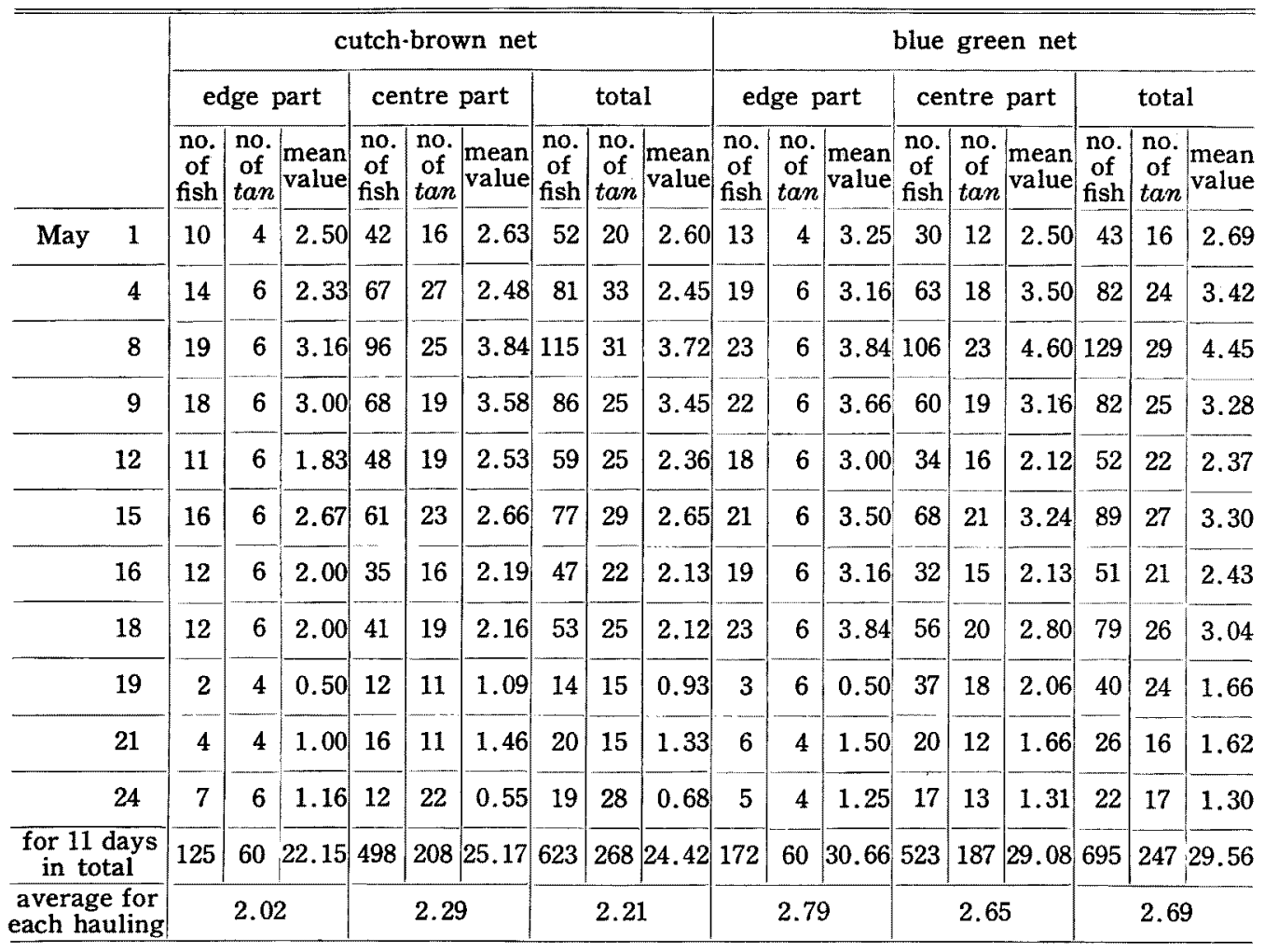

Table 2. Average haul per unit extension $(1 \tan )$ for differently coloured nets.

\begin{tabular}{|c|c|c|c|c|c|c|}
\hline \multirow{2}{*}{$\begin{array}{l}\text { notation } \\
\text { of the ship } \\
\text { employed }\end{array}$} & \multirow{2}{*}{ colour of net } & \multicolumn{3}{|c|}{$\begin{array}{l}\text { number of catch averaged for } \\
\text { each hauling }\end{array}$} & \multirow{2}{*}{$\begin{array}{l}\text { total number of } \\
\text { fish entangled; } \\
\text { total } \tan \text { of net } \\
\text { in parenthesis }\end{array}$} & \multirow{2}{*}{$\begin{array}{l}\text { the significance } \\
\text { level evaluated } \\
\text { by chi-square test }\end{array}$} \\
\hline & & edge part & centre part & total & & \\
\hline \multirow{2}{*}{$\alpha$ maru } & cutch-brown & 2.02 & 2.29 & 2.21 & $\begin{array}{c}623 \\
(268)\end{array}$ & \multirow{2}{*}{$\boldsymbol{P}<0.01$} \\
\hline & blue green & 2.79 & 2.65 & 2.69 & $\begin{array}{c}695 \\
(247)\end{array}$ & \\
\hline \multirow{2}{*}{$\alpha$ maru } & cutch-brown & 2.08 & 2.30 & 2.22 & $\begin{array}{c}534 \\
(312)\end{array}$ & \multirow{2}{*}{$P<0.01$} \\
\hline & gray & 2.72 & 2.76 & 2.77 & $\begin{array}{l}890 \\
(221)\end{array}$ & \\
\hline \multirow{2}{*}{$\beta$ maru } & cutch-brown & 1.60 & 1.54 & 1.57 & $\begin{array}{r}1,545 \\
(930)\end{array}$ & \multirow{2}{*}{$P<0.01$} \\
\hline & gray & 1.85 & 1.92 & 1.89 & $\begin{array}{l}2,010 \\
(967)\end{array}$ & \\
\hline
\end{tabular}



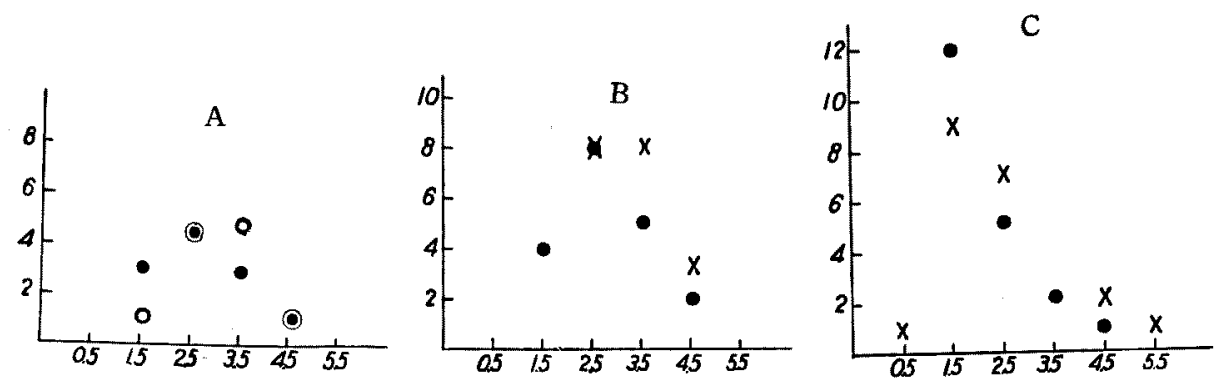

Fig. 3. Distribution of the frequency of fish entanglement per nuit tan. The values are given separately for each coloured net, each fishing boat, and each date of operation. Coordinate shows the frequency, abscissa shows the mean value or number of fish entangled per 1 tan of net in every day. A, B, $\alpha$ maru; C, $\beta$ maru. $\bigcirc$, blue-green;, cutchbrown; $\times$, gray.

色彩別の平均䧽網尾数を Table 2 K，及その嚬度を Fig. 3 K示す。Table 2 から $\alpha$ 丸及び $\beta$ 丸で何れ もカッチ色網が臛網不良であり，又 Fig. 3 の頻度についてみると， $\alpha$ 丸でカッチ色網が罹網不良の傾向が みられるが， $\beta$ 丸ではむ李り明らかでない。船別，色彩別，試駩網の補正漁獲尾数（この場合各着色網で投 網反数が違 5 ので夫々の試䮖網について少ない色彩の反数に多い方の着色網の反数を揃充て漁獲尾数を補正 した）についてカイ自乗鍫定により色彩の相違による羅網尾数の差異の有無について調べると Table 2 の 如く、いずれの場合も差埋が認められるが，檑々检討を要する点も多いので明らかでない。

終りに資料を貸与された大洋漁業株式会社北洋部に梁謝する。

文献

1）小池 篤・神田献二・小倉通男：本誌，24，1 (1958). 